\title{
Assessment of Marine Gas Hydrates and Associated Free Gas Distribution Offshore Uruguay
}

\author{
Juan Tomasini, ${ }^{1}$ Héctor de Santa Ana, ${ }^{1}$ Bruno Conti, ${ }^{1}$ Santiago Ferro, ${ }^{1}$ \\ Pablo Gristo, ${ }^{1}$ Josefina Marmisolle, ${ }^{1}$ Ethel Morales, ${ }^{1}$ Pablo Rodriguez, ${ }^{1}$ \\ Matías Soto, ${ }^{1}$ and Gerardo Veroslavsky ${ }^{2}$ \\ ${ }^{1}$ ANCAP, Exploración y Producción, Paysandú s/n y Avenida del Libertador, 6to piso, 11100 Montevideo, Uruguay \\ ${ }^{2}$ Departamento de Evolución de Cuencas, Facultad de Ciencias, Instituto de Ciencias Geológicas, Iguá 4225, \\ 11400 Montevideo, Uruguay \\ Correspondence should be addressed to Juan Tomasini, jtomasini@ancap.com.uy
}

Received 14 June 2011; Revised 29 July 2011; Accepted 2 August 2011

Academic Editor: Xuewei Liu

Copyright (C) 2011 Juan Tomasini et al. This is an open access article distributed under the Creative Commons Attribution License, which permits unrestricted use, distribution, and reproduction in any medium, provided the original work is properly cited.

\begin{abstract}
Natural gas hydrates are crystalline solids formed by natural gas (mainly methane) and water that are stable under thermobaric conditions of high pressure and low temperature. Methane hydrate is found in polar areas of permafrost and in offshore basins of continental margins. These accumulations may represent an enormous source of methane. Based on global estimations of methane concentration in natural gas hydrates, the methane content may be several times greater than those of technically recoverable, conventional natural gas resources. In the continental margin of Uruguay, seismic evidence for the occurrence of gas hydrate is based on the presence of (bottom simulating reflectors) BSRs in 2D seismic reflection sections. Here we present results regarding gas hydrates and associated free gas distribution assessment offshore Uruguay, based on BSR mapping and applying a probabilistic approach. A mean value of $25,890 \mathrm{~km}^{2}$ for the area of occurrence shows a great potential for this nonconventional resource, encouraging further research.
\end{abstract}

\section{Introduction}

Natural gas hydrates are crystalline solids formed by natural gas (mainly methane) and water that are stable under thermobaric conditions of high pressure and low temperature [1].

Methane hydrate occurs in sediments within and below thick permafrost in Arctic regions and in the subsurface of most continental margins where water depths are greater than 500 meters [2].

Gas hydrate accumulations may represent an enormous source of methane. Based on global estimations of methane concentrations, the methane content is about 2 to 10 times greater than those of technically recoverable conventional natural gas resources [2]. The existence of such a large methane hydrate resource has provided a strong global research incentive and international interest, which has grown in the last years.

The first acoustic indication of gas hydrate occurrence is given by presence of (bottom simulating reflection) BSR in seismic sections due to a significant change in acoustic impedance between sediment containing hydrates and sediments containing free gas $[3,4]$. The seismic appearance is parallel to seafloor reflection with a polarity reversal with respect to the seafloor.

The BSR is usually a good indication of gas trapped below the base of the gas hydrate stability zone (GHSZ) implying that gas hydrates are present [1]. On the other hand, gas hydrate can exist without creating a well-defined BSR, especially when gas fluxes are directed through faults or comparable permeable fluid pathways [1].

In offshore basins around the world the base of the GHSZ can have different seismic expressions such as continuous, segmented, and high-relief BSRs depending on the stratigraphic, fluid, and geothermal setting [5].

Another seismic response associated with the presence of gas hydrates in marine sediment is the blanking (reduction of the amplitude of seismic reflections). It can be used to identify sediments, in which hydrates have been formed. However, blanking is not a good indicator of the base of 


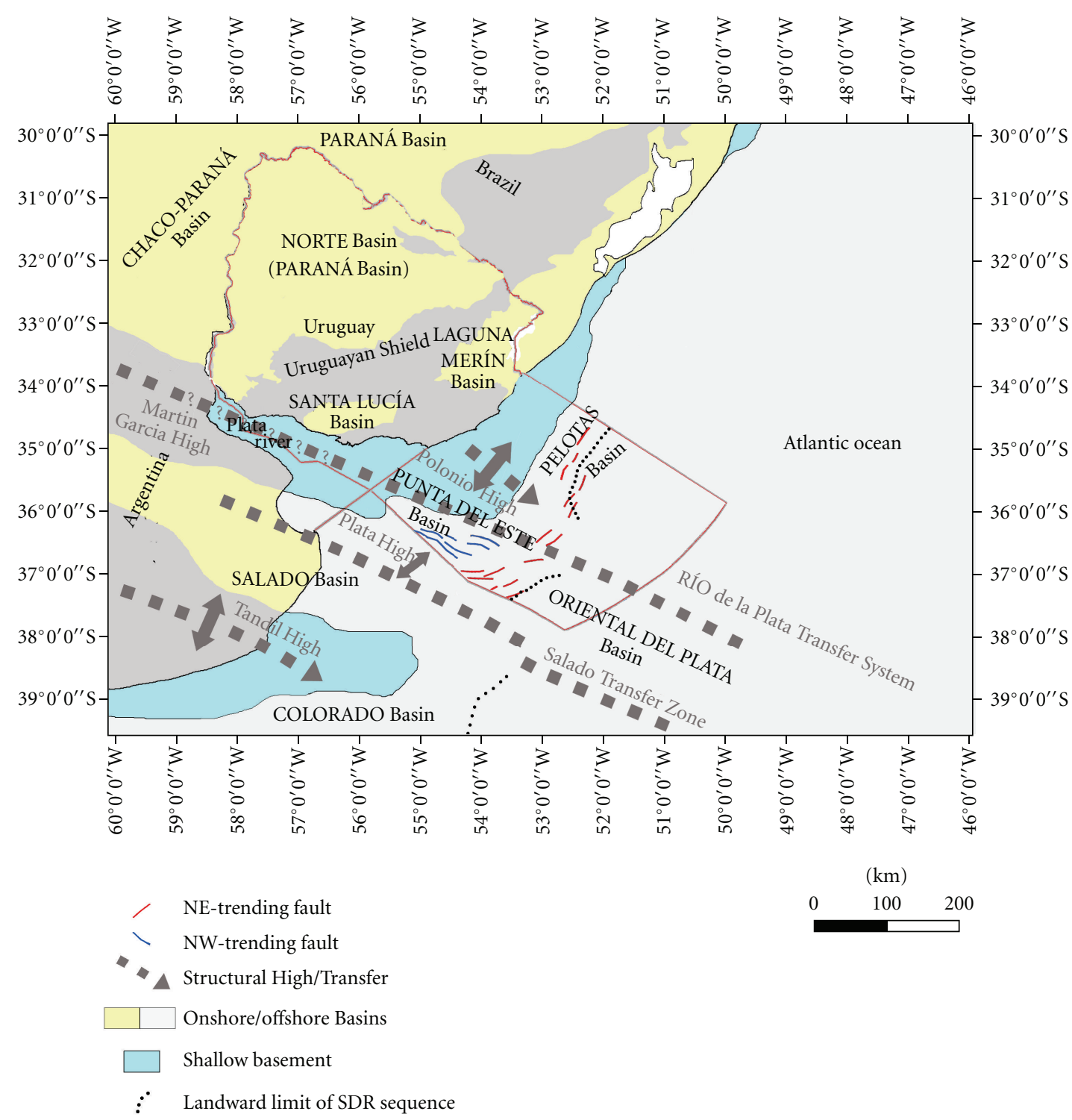

FIgURE 1: Sedimentary basins of Uruguay. After Soto et al. [7].

GHSZ because there are several possibilities leading to signal attenuation, like the original or diagenetic character of strata as well as artifacts produced during seismic processing [1].

The study area for this work is the continental margin of Uruguay. This margin was formed during continental rifting and seafloor spreading, which included strong volcanic activity [6]. Three offshore basins were created during this process: Punta del Este, Pelotas, and Oriental del Plata basins (Figure 1) [7], which have a total extent, within the 200 nautical miles limit, of near $85,000 \mathrm{~km}^{2}$ and a maximum volcano-sedimentary fill of $8,000 \mathrm{~m}$ based on seismic data [7]. This volcano-sedimentary fill comprises Juro-Cretaceous to recent sequences and is worth to mention the presence of a Paleozoic prerift correlative with Parana Basin records.

These basins are genetically related to the Western Gondwana breakup ( $130 \mathrm{Ma}$ ago) and the subsequent development of the Atlantic Ocean and thus, are part of an important series of depocenters which include offshore hydrocarbon productive basins such as Santos and Campos basins (Brazil) and also the conjugate Orange Basin (South Africa and Namibia) [7].

The Punta del Este Basin is a mainly NW-SE trending aborted rift, perpendicular to the general trend of the continental margin [8]. In contrast, the NE-SW trending Pelotas Basin belongs to the flexural border of a precursor rift structure and continues in the Brazilian margin up to the Florianópolis Platform [7].

The Punta del Este and Pelotas basins are separated in shallow waters by the Polonio High. The distal part of both basins, where the Polonio High is not present and comprises a thick Cenozoic package, is called by some authors the Oriental del Plata Basin (Figure 1) $[9,10]$, which according to a recent redefinition has been restricted to the 
TABle 1: Offshore Uruguay seismic survey's details.

\begin{tabular}{lcccc}
\hline Survey & Acquisition company & Year & Number of lines & Length $(\mathrm{km})$ \\
\hline UR70 & CGG & 1970 & 12 & 2571 \\
UR71 & CGG & 1971 & 32 & 2696 \\
UR74 & GSI & 1974 & 35 & 2578 \\
UR75 & GSI & 1975 & 28 & 1897 \\
UR77 & GSI & 1977 & 16 & 1050 \\
UR82 & WESTERN & 1982 & 23 & 1402 \\
UR02 & CGG & 2002 & 6 & 1850 \\
UR07 & WAVEFIELD-INSEIS & 2007 & 32 & 7125 \\
UR08 & WAVEFIELD-INSEIS & 2008 & 22 & 2909 \\
\hline
\end{tabular}

southern region of the continental margin, comprising only transitional and oceanic crust [7].

Different water masses and currents coexisting in the area play a fundamental role in the occurrence of gas hydrates considering temperature, salinity, and pressure conditions as well as sediment erosion and deposition.

Today, the continental margin of Uruguay is characterized by strong contour currents and the important input of huge amounts of sediments from the Río de la Plata river [11].

The area comprises a very complex and dynamic oceanographic regime. At surface level, dense and cold antarctic water masses from the Malvinas/Falkland Current flowing northward converge with the warm and saline Brazil Current flowing towards the South, resulting in the Brazil-Malvinas Confluence [12].

However, the confluence is not confined to surface currents, and also the interaction of intermediate water masses results in a complicated flow pattern. While antarctic intermediate water (AAIW) and circumpolar deep water (CDW) are flowing northward, the southward flowing north atlantic deep water (NADW) separates the CDW into Upper-CDW and Lower-CDW. The deep basins are under the influence of the antarctic bottom water (AABW) [13].

Interaction between these currents strongly affects sedimentary processes as well as margin morphology. The existence of strong contour currents leads to the generation of a large Contouritic Depositional Complex, which at least extends from southern Argentine margin to the margin of Uruguay, including various kinds of erosive and depositional sedimentary features [14].

Although strong deep currents are not favorable for organic matter deposition and preservation, contouritic deposits have been frequently associated both with conventional hydrocarbon reservoirs and with gas hydrate accumulations [15]. Indeed, big hydrate accumulations inferred from BSRs have been found in contouritic deposits along Atlantic margin [15].

In addition, these along-slope processes interact with downslope sedimentary gravitational processes, which have a large impact in the study area. In this way, mainly in the southern region (Punta del Este Basin), a series of submarine channels are developed.
Conventional hydrocarbon reservoirs associated with turbiditic sequences are well known while methane hydrate accumulations in this type of sequences have been reported as drilling targets offshore Japan [16].

First work regarding gas hydrates offshore Uruguay was performed by de Santa Ana et al. [17], where the presence of a BSR was recognized for the first time. Gas hydrate distribution and thickness were afterwards estimated based on the available seismic grid allowing first approximations on resource potential. Initial determination of mineralized area was $5,000 \mathrm{~km}^{2}$ resulting in 86 trillion cubic feet (TCF) of natural gas under normal conditions [17], based on seismic information available at that time in nondigital format.

In 2005, the presence of gas hydrates was reported by Neben et al. from the German institute BGR after a 2D seismic survey in the area [18]. In this work, the BSR area was mapped from seismic sections acquired at that survey, resulting in a minimum of approximately $7,000 \mathrm{~km}^{2}$.

Even if the BSR represents the most reliable indication of the existence of gas hydrates within the study area, high methane concentrations and (anaerobic oxidation of methane) AOM within the upper few meters of the sediments suggest the existence of methane hydrate in the study area [19].

Hydrocarbon generation and migration offshore Uruguayn have been confirmed through fluid inclusion analysis [20], which were recognized in synrift and postrift sequences from two wells drilled in the area [21].

In 2008 , oil seeps were identified by satellite images [10, 22], and poststack processing for gas chimney identification [23] was performed on 2D seismic sections, which showed vertical disturbances of the seismic signal. These signal anomalies, reaching into higher depths, were interpreted as hydrocarbon migration pathways and suggest a thermogenic origin of the gases that reach gas hydrate reservoirs [24].

All these evidences of hydrocarbon generation strongly indicate that thermogenic provenance of gas to form gas hydrates in upper sequences, as the only or combined with biogenic gas origin, is very plausible.

In this work, the integration of a dense grid of different 2D seismic surveys acquired offshore Uruguay was done for first time in order to identify the base of the GHSZ and assess gas hydrate and associated free gas distribution within 


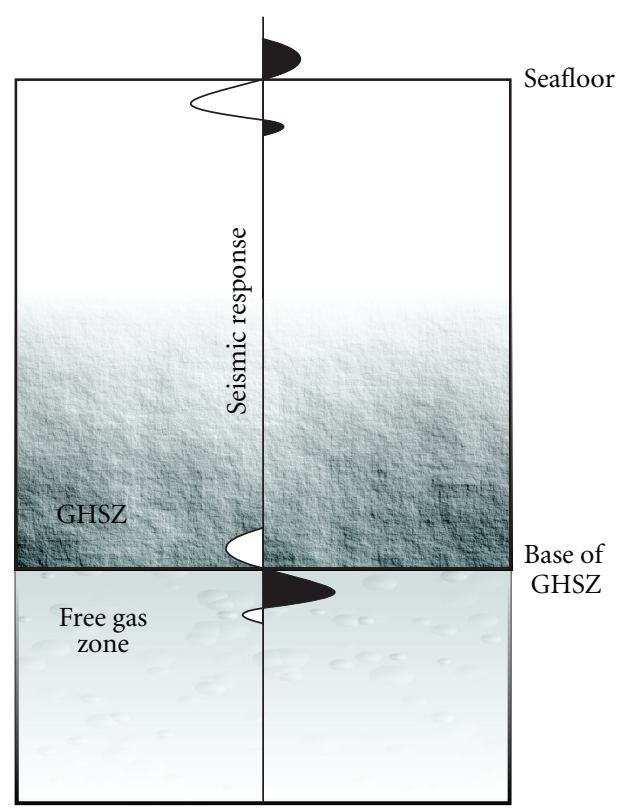

Figure 2: Theoretical response of seafloor and base of GHSZ.

the studied area. A probabilistic approach was considered in order to reflect the uncertainty of the interpretation, taking into account both high and low side of the mapped area and reporting a final mean value.

\section{Methodology}

For this work we used 2D reflection seismic data, acquired during different surveys for hydrocarbon exploration offshore Uruguay between 1970 and 2008.

More than $24,000 \mathrm{~km}$ of $2 \mathrm{D}$ reflection seismic sections were interpreted (Table 1). Seismic-stratigraphic interpretation was performed using commercial seismic interpretation software, considering reflectors attributable to the base of GHSZ, based on its theoretical response (Figure 2) and known characteristics of BSRs $[1,3,4]$.

Once seismic interpretation was performed on available sections, gas hydrate and free gas spatial distribution was mapped and calculated.

\section{Results}

Interpretation of the base of GHSZ from seismic data in the area shows a widespread distribution of gas hydrate bearing sediments.

Continuous and segmented BSRs were observed while "high relief" BSRs were not identified. In Figure 3 we present an example of seismic wiggle showing the characteristic polarity reverse of BSR regarding the seafloor. For some sections, acoustic blanking is observed above a BSR crosscutting sedimentation strata (Figure 4). In Figure 5 we present a seismic section from UR08 survey shot at Punta del Este Basin; a clear example of BSR is observed while seismic anomalies of enhanced amplitudes are present below it.

BSR was interpreted in UR70, UR71, UR74, UR77, UR82, UR02, UR07, and UR08 surveys. It is present below water

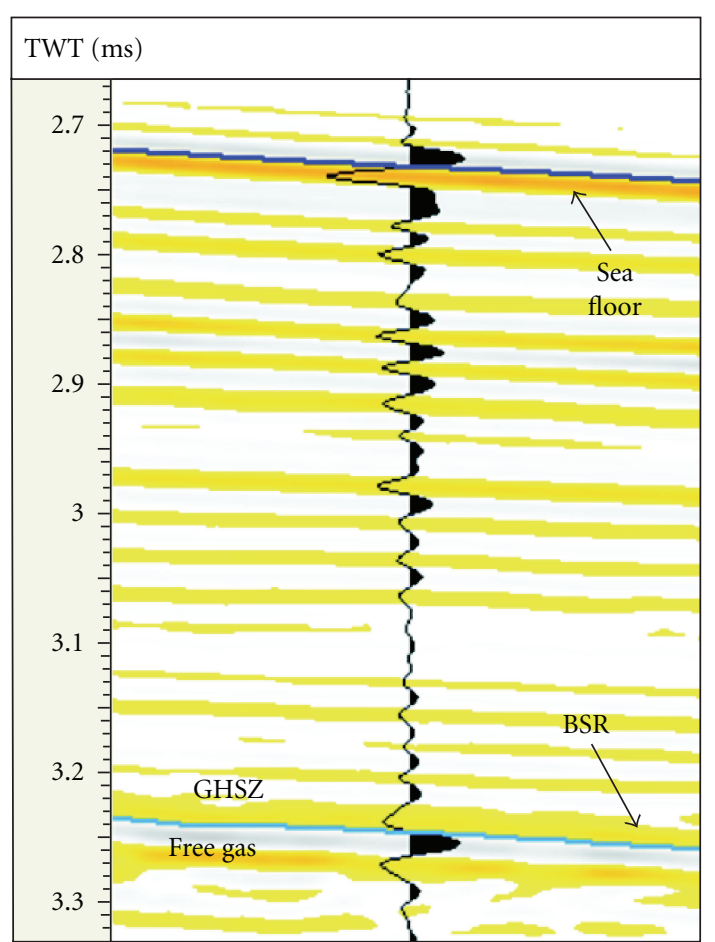

FIGURE 3: Seismic response of seafloor and base of GHSZ in seismic section from the area.

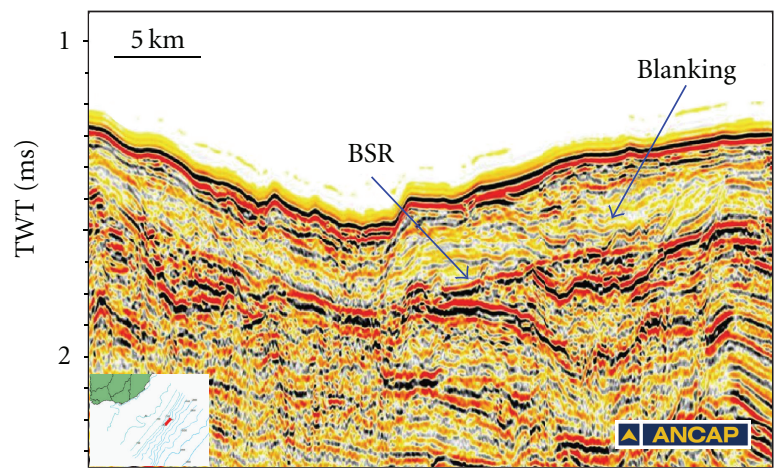

FIGURE 4: Section UR82_004 from Pelotas Basin. BSR present at 1982 survey showing blanking at the hydrate zone.

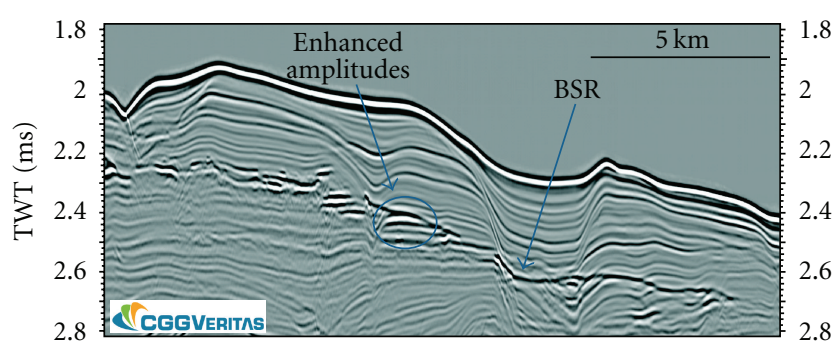

Figure 5: Seismic section from Punta del Este Basin showing a BSR at $0.330 \mathrm{sec}$ TWT from the seafloor and enhanced amplitudes bellow the BGHSZ. Modified from [24]. Courtesy of CGG Veritas. 


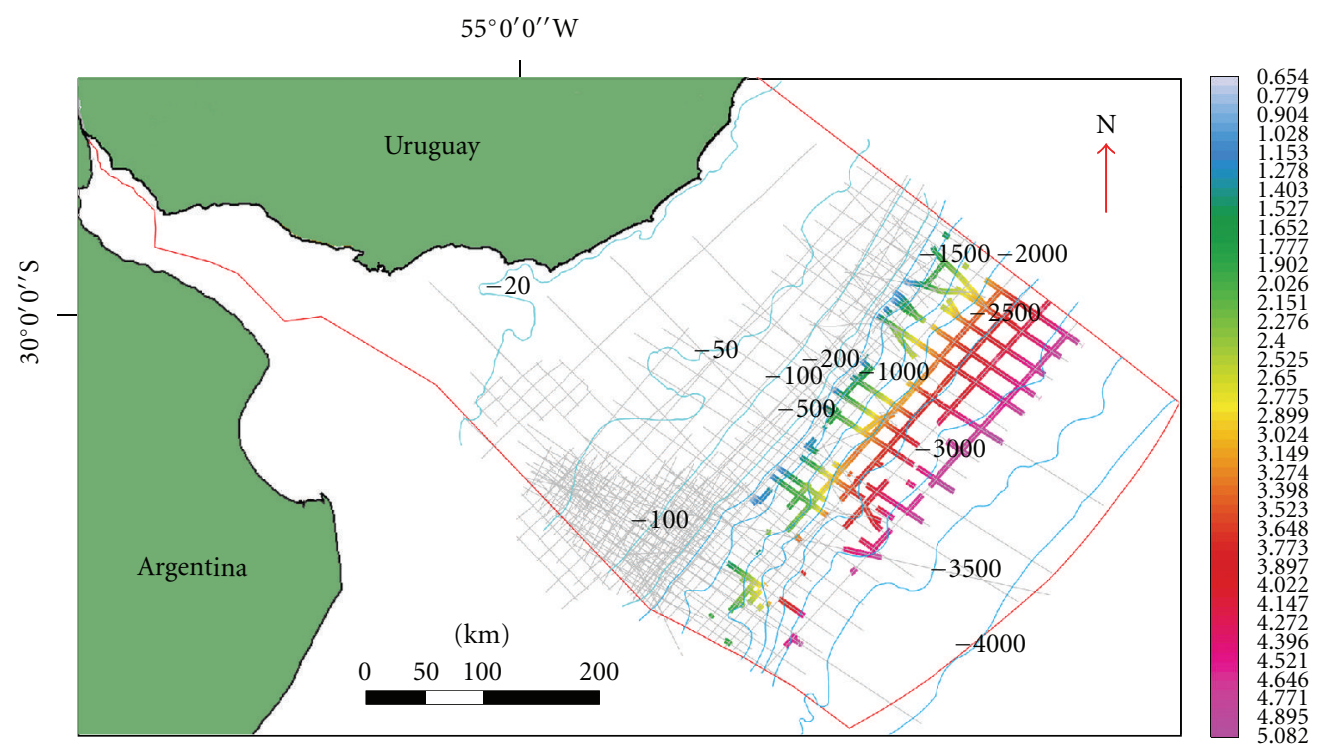

FIGURE 6: Results of BSR interpretation offshore Uruguay, showing a widespread distribution of gas hydrate bearing marine sediments. Color scale represents reflector depth in ms (TWT).

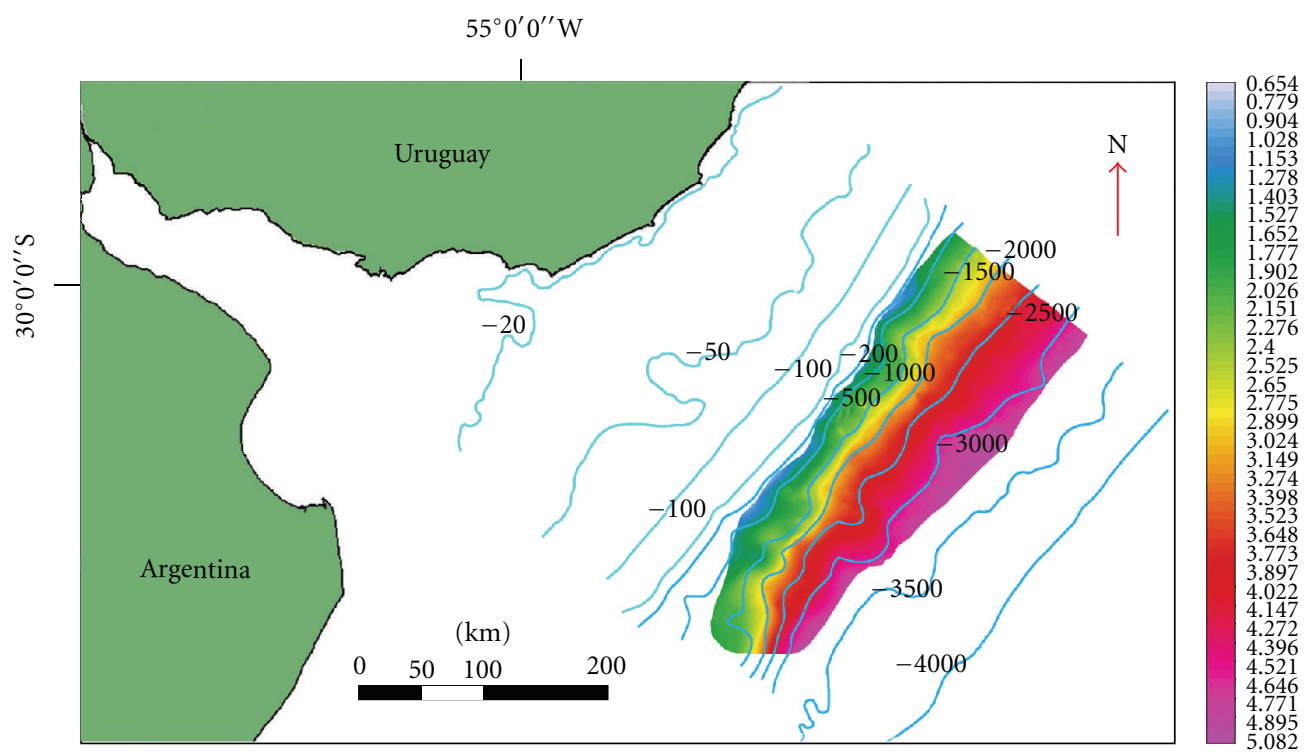

Figure 7: Maximum area of gas hydrate and free gas distribution, considering the envelope of BSR interpretations.

depths from 500 to $3,200 \mathrm{~m}$ and has high continuity in Pelotas Basin but is more discontinuous at Punta del Este Basin (Figure 6).

BSR interpretations showed in Figure 6 corresponds to $25,000 \mathrm{~km}^{2}$ and for probabilistic calculation purposes is considered as the P50 of the occurrence area.

For the high side, we have mapped the total maximum area of sediments that may contain gas hydrates offshore Uruguay considering the envelope of BSR interpretations. The total maximum area corresponds to $32,500 \mathrm{~km}^{2}$ (show in Figure 7) and was considered as a P5 percentile ("larger than" convention).
The distribution chosen for the area assessment was of log-normal type as being the most common followed by nature and in particular for resource area [25]. Considering $\mu=\operatorname{Ln}(\mathrm{P} 50)$ and truncation for values greater than P1 in order to disregard the extremely high values of the distribution, the resulting mean value for the area is $25.89 \times$ $10^{3} \mathrm{~km}^{2}$ as shown in Figure 8.

\section{Discussion}

In Figure 4, acoustic blanking is observed above BSR. As showed by Max et al. [1], this seismic character may have a relation with gas hydrate presence. In this case, the fact of finding 


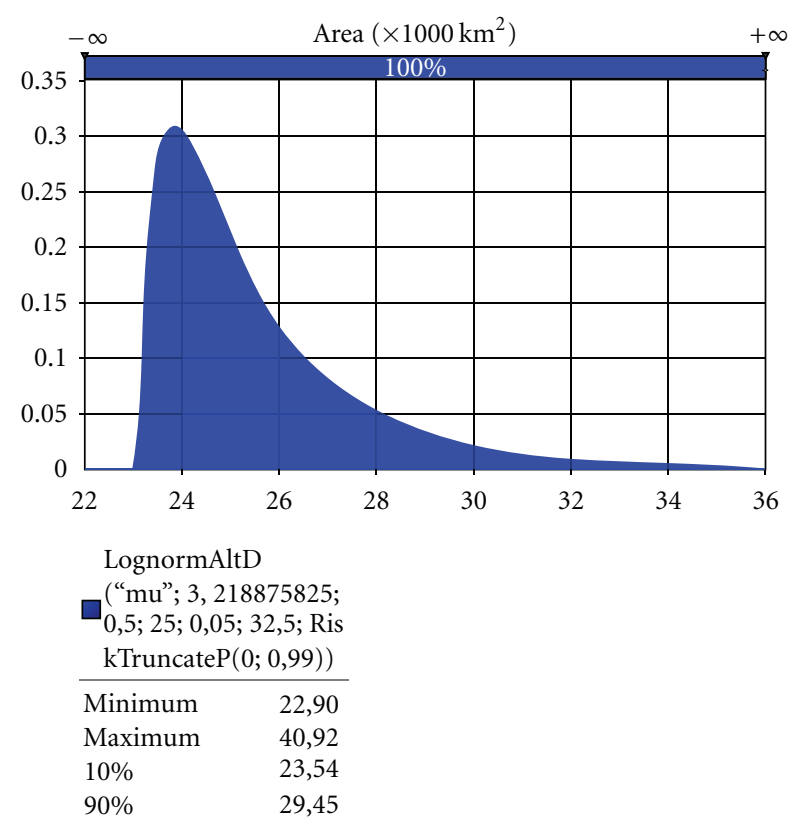

Figure 8: Probability density function of the lognormal distribution of gas hydrates occurrence area offshore Uruguay. P90 = $23.54 \times 10^{3} \mathrm{~km}^{2} ; \mathrm{P} 10=29.45 \times 10^{3} \mathrm{~km}^{2}$.

blanking associated with BSR supports the interpretation of hydrate occurrence. In Figure 5, seismic anomalies of enhanced amplitudes suggests the presence of free gas below the base of GHSZ opening new opportunities for further research on subhydrate prospects exploration in the area.

At basin scale, as water depth increases, the base of the GHSZ progressively extends farther below the seafloor. This increment in thickness of GHSZ responds to pressure increasing and temperature decreasing at higher water depths as showed by Max et al. [1]. As reported for several offshore basins around the world [2], gas hydrate occurrence offshore Uruguay starts developing at approximately $500 \mathrm{~m}$ of water depth (Figure 6). This agrees with the P-T seafloor conditions for phase equilibrium [26] of approximately 4903 $\mathrm{KPa}, 5^{\circ} \mathrm{C}$, and seawater salinity of $35 \mathrm{PSU}$ for a $\mathrm{CH}_{4}+\mathrm{NaCl}$ $+\mathrm{H}_{2} \mathrm{O}$ system [27]. Further studies are needed in order to assess possible gas hydrate formation and destabilization cycles with eustasy and its effects on seafloor stability and geohazards potential.

Towards NE direction, BSR interpretation stops at or close to the end of strike lines, as the available database does not cross the Uruguay-Brazil maritime boundary. Nevertheless, interpreted gas hydrate area offshore Uruguay is probably part of a much greater gas hydrate province, shared with Brazil, extending further north at the Pelotas Basin. This basin has the largest gas hydrate occurrence of the Brazilian coast $[28,29]$.

At SE direction, BSR was interpreted up to a maximum water depth of $3,200 \mathrm{~m}$. Below this ultradeep water domains, parallelism of sedimentary reflectors makes the identification of BSR difficult. Nevertheless, gas hydrate may be present beyond this range of water depth as found at other locations around the world and reported by Booth et al. [30].
Distribution of gas hydrate deposits offshore Uruguay presents high continuity in the north area (Pelotas Basin) but is more discontinuous in the Punta del Este Basin (while it cannot be assessed in the Oriental del Plata Basin due to limited seismic data; Figure 6). This may be due to various factors, including the presence of submarine channels. The existence of this kind of morphologies associated with sediment transport processes down slope has a special importance in Punta del Este Basin and may be the cause of BSR interpretation absence in certain zones, mainly due to complex sedimentary disposition.

In addition, the base of GHSZ has different expressions depending on lithological characteristics of sediments, leading to cases where the BSR may not be evident. In these cases, different relative sand-clay contents may play an important role.

On the other hand, the presence of BSRs indicates the coexistence between Free Gas and Gas Hydrate phases therefore situations may exist where sediments contain hydrates but not enough free gas at the phase boundary as to generate a BSR-like seismic response.

All these different aspects regarding BSR imaging and interpretation support the importance of the probabilistic approach applied to report area of occurrence.

\section{Conclusions}

Gas hydrate and associated free gas occurrence presents a widespread distribution offshore Uruguay, resulting in a mean value of $25,890 \mathrm{~km}^{2}$, being much higher than reported by previous studies. Results show a great potential for this nonconventional resource, encouraging further research.

Further studies are needed about possible gas hydrate formation and destabilization cycles that may take place at the landward limit of the occurrence zone in order to evaluate its effect on seafloor stability and geohazard potential.

Seismic evidence of discrete free gas accumulations below the gas hydrate stability zone through amplitude anomalies was found. Those accumulations could be considered as subhydrate prospects and may play an important role considering future gas field developments offshore Uruguay.

From the exploratory point of view, determination of locations with good reservoir characteristics is critical for a comprehensive resource assessment.

Identification and quantification of high porosity and permeability sand deposits within the mapped area and GHSZ is needed in order to define exploratory targets. This will be the key element for the eventual development of gas hydrate prospects offshore Uruguay, once international research manages to prove that methane from marine gas hydrates can be produced as a technically safe, environmentally compatible, and economically competitive energy resource.

\section{Acknowledgments}

This work was performed in the framework of the Project FSE_2009_53 from the ANII. CGGVeritas and ANCAP are acknowledged for the permission to publish figures of seismic sections. 


\section{References}

[1] M. D. Max, A. H. Johnson, and W. P. Dillon, Economic Geology of Natural Gas Hydrate, Springer, 2006.

[2] Committee on Assessment of the Department of Energy Methane Hydrate Research and Development Program: Evaluating Methane Hydrate as a Future Energy Resource, Realizing the Energy Potential of Methane Hydrate for the United States, 2010.

[3] E. D. Sloan, Clathrate Hydrates of Natural Gas, Marcel Dekker, New York, NY, USA, 1998.

[4] C. K. Pecher and W. S. Holbrook, "Seismic methods for detecting and quantifying gas hydrates," in Natural Gas Hydrate in Oceanic and Permafrost Environments, M. D. Max, Ed., pp. 257-294, Kluwer Dordrecht, 2000.

[5] B. Shedd, P. Godfriaux, M. Frye, R. Boswell, and D. Hutchinson, Occurrence and Variety in Seismic Expression of the Base of Gas Hydrate Stability in Gulf of Mexico, USA, Fire in The Ice, Methane Hydrate Newsletter, 2009.

[6] D. Franke, S. Neben, S. Ladage, B. Schreckenberger, and K. Hinz, "Margin segmentation and volcano-tectonic architecture along the volcanic margin off Argentina/Uruguay, South Atlantic," Marine Geology, vol. 244, no. 1-4, pp. 46-67, 2007.

[7] M. Soto, E. Morales, G. Veroslavsky, H. de Santa Ana, N. Ucha, and P. Rodríguez, "The continental margin of Uruguay: Crustal architecture and segmentation," Marine and Petroleum Geology, vol. 28, pp. 1676-1689, 2011.

[8] F. A. Stoakes, C. V. Campbell, R. Cass, and N. Ucha, "Seismic stratigraphic analysis of the Punta del Este Basin, offshore Uruguay, South America," American Association of Petroleum Geologists Bulletin, vol. 75, no. 2, pp. 219-240, 1991.

[9] H. de Santa Ana, N. Ucha, and G. Veroslavsky, "Geología y potencial hidrocarburífero de las cuencas offshore de Uruguay," in Proceedings of the 5th Seminario Internacional: Exploración y Producción de Petróleo y Gas, Lima, Peru, 2005.

[10] H. de Santa Ana, G. Veroslavsky, and E. Morales, "Potencial exploratorio del offshore de Uruguay," Revista de la Industria Petrolera, no. 12, pp. 48-59, 2009.

[11] D. A. Giberto, C. S. Bremec, E. M. Acha, and H. Mianzan, "Large-scale spatial patterns of benthic assemblages in the SW Atlantic: the Río de la Plata estuary and adjacent shelf waters," Estuarine, Coastal and Shelf Science, vol. 61, no. 1, pp. 1-13, 2004.

[12] R. G. Peterson and L. Stramma, "Upper-level circulation in the South Atlantic Ocean," Progress in Oceanography, vol. 26, no. 1, pp. 1-73, 1991.

[13] F. J. Hernández-Molina, M. Paterlini, L. Somoza et al., "Giant mounded drifts in the Argentine Continental Margin: origins, and global implications for the history of thermohaline circulation," Marine and Petroleum Geology, vol. 27, no. 7, pp. 1508-1530, 2010.

[14] F. J. Hernández-Molina, M. Paterlini, R. Violante et al., "Contourite depositional system on the Argentine slope: an exceptional record of the influence of Antarctic water masses," Geology, vol. 37, no. 6, pp. 507-510, 2009.

[15] A. R. Viana, "Chapter 23 Economic Relevance of Contourites," Developments in Sedimentology, vol. 60, pp. 491-510, 2008.

[16] T. Saeki, T. Fujii, T. Inamori et al., "Delineation of methane hydrate concentrated zone using 3D seismic data in the eastern Nankai Trough," in Proceedings of the 6th International Conference on Gas Hydrates (ICGH '08), Vancouver, Canada, July 2008.

[17] H. de Santa Ana, N. Ucha, L. Gutiérrez, and G. Veroslavsky, "Gas hydrates: estimation of the gas potential from reflection seismic data in the continental shelf of Uruguay," Revista de la Sociedad Uruguaya de Geología, no. 11, pp. 46-52, 2004.

[18] S. Neben, B. Schreckenberger, J. Adam et al., Research Cuise BGR04, ARGURU - Geophysical Investigations Offshore Argentine and Uruguay with Akademik Alexandr Karpinsky. Buenos Aires-Buenos Aires, 19/11/2004-19/12/2004. Cruise Report and Preliminary Results, Bundesanstalt für Geowissenschaften und Rohstoffe, Hannover, Germany, 2005.

[19] C. Hensen, M. Zabel, K. Pfeifer et al., "Control of sulfate porewater profiles by sedimentary events and the significance of anaerobic oxidation of methane for the burial of sulfur in marine sediments," Geochimica et Cosmochimica Acta, vol. 67, no. 14, pp. 2631-2647, 2003.

[20] S. A. Barclay, R. H. Worden, J. Parnell, D. L. Hall, and S. M. Sterner, "Assessment of fluid contacts and compartmentalization in Sandstone reservoirs using inclusions: an example from the magnus oil field, North Sea," AAPG Bulletin, vol. 84, no. 4, pp. 489-504, 2000.

[21] G. F. Tavella and C. G. Wright, "Cuenca del Salado," in Geología y Recursos Naturales de la Plataforma Continental Argentina, V. A. Ramos and M. A. Turic, Eds., pp. 95-116, 1996, Relatorio del XIII ${ }^{\circ}$ Congreso Geológico Argentino y III $^{\circ}$ Congreso de Exploración de Hidrocarburos, Buenos Aires.

[22] H. de Santa Ana, G. Veroslavsky, and E. Morales, "Estado exploratorio de la región costa afuera de Uruguay," in Proceedings of the 7th Congreso de Exploracion y Desarrollo de Hidrocarburos, pp. 649-657, Instituto Argentino del Petroleo y del Gas, Mar del Plata, Argentina, 2008.

[23] P. Meldahl, R. Heggland, B. Bril, and P. de Groot, "Identifying faults and gas chimneys using multiattributes and neural networks," Leading Edge, vol. 20, no. 5, pp. 474-482, 2001.

[24] J. Tomasini, H. de Santa Ana, and A. Johnson, "Identification of new seismic evidence regarding gas hydrate occurrence and gas migration pathways offshore Uruguay," in Proceedings of the AAPG 2010 Annual Convention \& Exhibition, New Orleans, La, USA, 2010.

[25] E. C. Capen, "Probabilistic reserves! Here at last?" SPE Reservoir Evaluation and Engineering, vol. 4, no. 5, pp. 387394, 2001.

[26] Z. Lu and N. Sultan, "Empirical expression for gas hydrate stability law, its volume fraction and mass-density at temperatures $273.15 \mathrm{~K}$ to $290.15 \mathrm{~K}$," Geochemical Journal, vol. 42, no. 2, pp. 163-175, 2008.

[27] J. Tomasini, H. de Santa Ana, P. Gristo et al., "Determination of Hydrate Formation Gases for Marine Gas Hydrates Offshore Uruguay," Project FSE_2009_53, ANII. In preparation.

[28] S. Oliveira, O. Vilhena, and E. da Costa, "Time-frequency spectral signature of Pelotas Basin deep water gas hydrates system," Marine Geophysical Researches, vol. 31, no. 1, pp. 8997, 2010.

[29] A. Sad, D. Silveira, S. Silva, R. Maciel, and M. Machado, "Marine gas hydrates along the Brazilian margin," in Proceedings of the ABGP/AAPG International Conference and Exhibition, Rio de Janeiro, Brazil, 1998, AAPG Search and Discovery Article \#90933.

[30] J. S. Booth, M. M. Rowe, and K. M. Fischer, "Offshore gas hydrate sample database with an overview and preliminary analysis," Open-File Report 96-272, U.S. Geological Survey, 1996, http://pubs.usgs.gov/of/1996/of96-272/. 

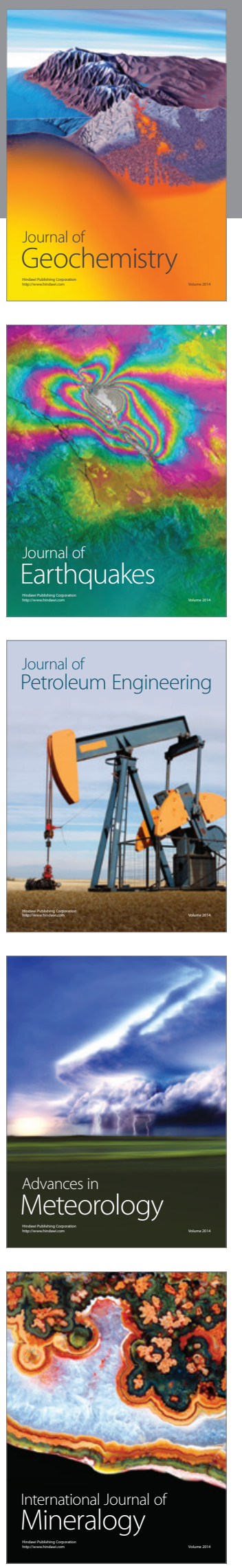
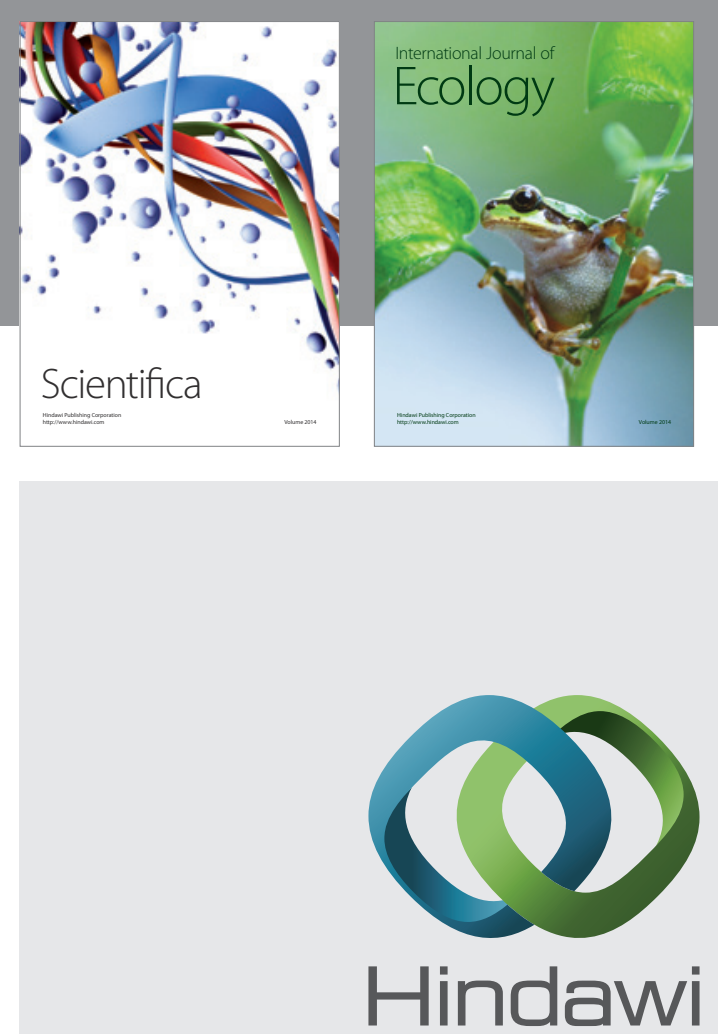

Submit your manuscripts at http://www.hindawi.com
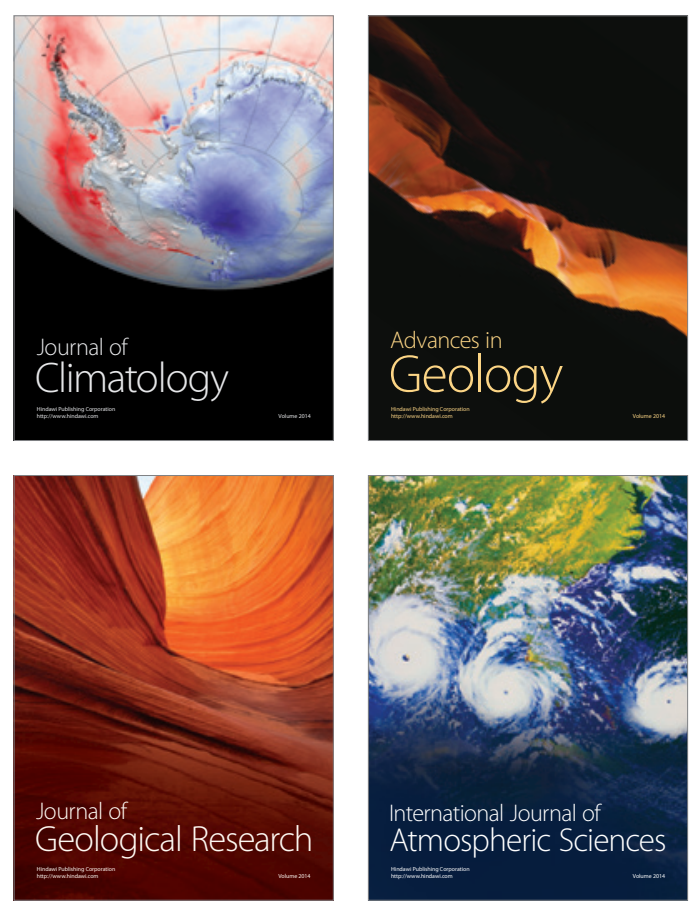
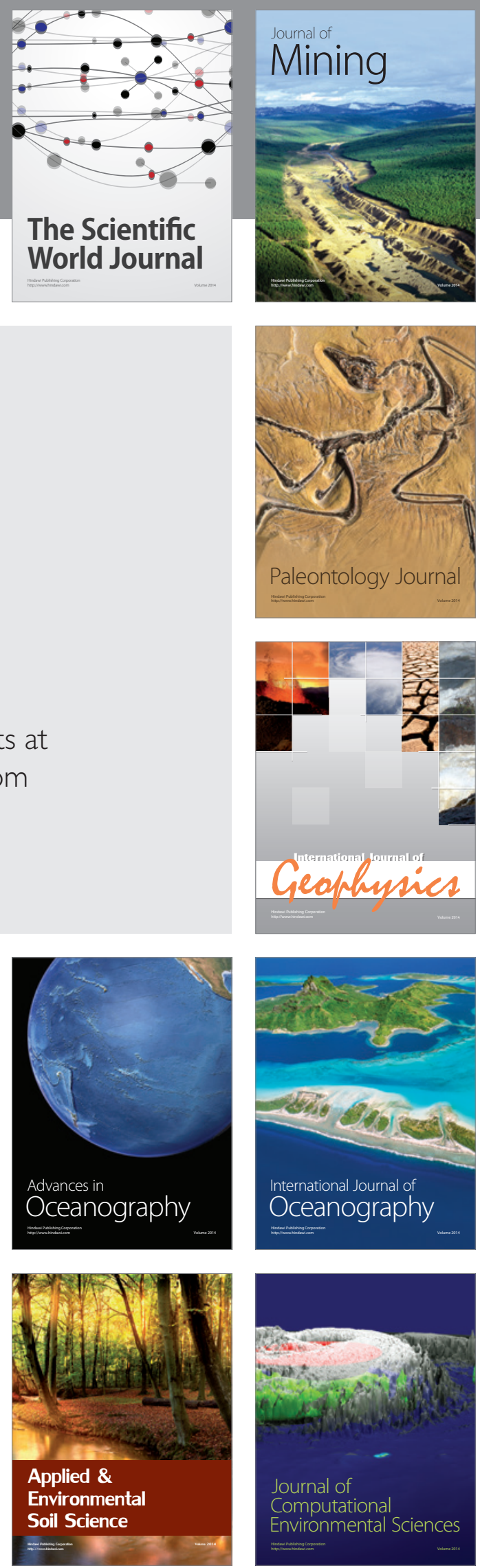